\title{
Immune Response to Hepatitis B Vaccine in Health-Care Workers
}

\author{
Maha M. Hussein'1, Manal M. Hussein² \\ Internal Medicine department Ain Shams University ${ }^{1}$, Clinical Pathology Department Ain \\ Shams University ${ }^{2}$.
}

\begin{abstract}
:
Health care workers (HCWs) constitute a high-risk population of HBV infection. There are limited data on the efficacy of vaccination in HCWs in Egypt.

The aim of this study was to evaluate the immune response to hepatitis B recombinant vaccine in HCWs in our hospital.

Methods: $100 \mathrm{HCWs}$ who completed three doses of intramuscular immunization with recombinant DNA hepatitis $\mathrm{B}$ vaccine (Engerix-B) at different time periods during the last 5 years were examined for hepatitis B surface antigen ( $\mathrm{HBs} \mathrm{Ag}$ ), anti hepatitis B surface antibodies (anti HBs Abs) and hepatitis B core antibodies (HBc Abs).

Results: $96 \%$ of HCWs showed seroconversion (anti $\mathrm{HBs} \geq 10 \mathrm{IU} / \mathrm{L}$ ); $92 \%$ good responders (anti $\mathrm{HBs}>100 \mathrm{IU} / \mathrm{L}$ ) and 4\% weak responders (anti HBs $=10-100 \mathrm{IU} / \mathrm{L}$ ). The HBsAg and $\mathrm{HBc} \mathrm{Ab}$ were never detected among the entire responders. Younger age had higher anti HBs titer than older HCWs. The non responders were 4\%; two of them had evidence of chronic hepatitis B infection.

Conclusion: Vaccination against HBV in HCWs in Egypt is cost effective and achieved good response rate. Screening for Hepatitis $B$ infection before vaccination should be considered to detect those with undiagnosed infection.
\end{abstract}

Key word: Hepatitis B vaccine, Immune response, Egypt, HCWs

\section{Introduction:}

Hepatitis B virus (HBV) infection has been a major global cause of morbidity and mortality (Kwon and Lee, 2011). It is estimated that 350 million patients are chronically infected worldwide and that around half a million die every year from end stage complications of persistent infection (Hennig et al., 2008). Health care workers (HCWs) are at increased risk of occupational exposure to HBV infection (Gholamzadeh and Serati, 2006 and Thakur et al., 2010).

Fortunately, the currently available hepatitis B Vaccine are extremely safe and have an efficacy of $>90$ percent. Thus HBV infection can potentially be eradicated through global vaccination (Ni et al., 2001 and Chang, 2011). In general, no necessity for booster doses for fully vaccinated immunocompetent individuals (Van Damme and Van Herck, 2007 and Gabbuti et al., 2007). The post vaccination antibody testing and regular testing for antibodies is recommended only to high-risk subjects, especially to health care workers and subjects with immunodeficiency (Zannolli and Morgese , 1997 and Pallás Alvarez et al., 2000).

Although the majority of persons vaccinated against hepatitis B successfully 
respond to vaccination, around $5-15 \%$ of persons may not respond. "Vaccine nonresponder" is a person who does not develop protective surface antibodies after completing two full series of the hepatitis B vaccine and for whom an acute or chronic hepatitis B infection has been ruled out (Scolnick et al., 1985).

The standard anti-HBV vaccination elicits protective anti-HBs levels (above $10 \mathrm{IU} / \mathrm{L}$ ) in most people (Pallás Alvarez et al., 2000). According to the anti-HBs produced in response to the recombinant $\mathrm{HBV}$ vaccine; low serum level $<10 \mathrm{IU} / \mathrm{L}$ is evaluated as lack of protection, serum level $=10-100 \mathrm{IU} / \mathrm{L}$ corresponds to weak protection and $>100 \mathrm{IU} / \mathrm{L}$ is considered as sufficient protection (Zannolli and Morgese, 1997, Shatat et al., 2000 and Platkov et al., 2003).

There are limited data about the rates of post vaccination seroconversion in Egypt among high risk groups especially HCWs who received recombinant hepatitis $B$ vaccination.

\section{Aim of the Study:}

To assess immune response to $\mathrm{HBV}$ vaccine in HCWs who had completed three doses of hepatitis B recombinant vaccine.

\section{Subjects and Methods:}

This study was conducted on HCWs of Gastroenterology department of Ain Shams University Hospitals. An interview was done to enroll subjects who completed three doses of intramuscular hepatitis B recombinant vaccine (Engerix $20 \mu \mathrm{g}$ offered in infection control unit in the last five years) at $0,1,6$ months intervals. Subjects with diabetes mellitus, history of infection with $\mathrm{HBV}$ or $\mathrm{HCV}$, renal impairment or those on steroids or immunosuppressive therapy were excluded.

\section{Study design:}

100 subjects who fulfill the previous conditions were randomly selected to provide a blood sample for anti HBs Ab, $\mathrm{HBs} \mathrm{Ag}$ and $\mathrm{HBc} \mathrm{Ab}$ testing. Anti $\mathrm{HBs} \mathrm{Ab}$ is done to assess the immune response to $\mathrm{HBV}$. $\mathrm{HBs} \mathrm{Ag}$ and $\mathrm{HBc} \mathrm{Ab}$ are done to exclude HBV infection. Demographic data and BMI were recorded for all participants. Seroconversion was defined as development of Anti HBs $\geq 10 \mathrm{IU} / \mathrm{L}$.

According to the measured anti-HBs $\mathrm{Ab}$ level, participants were classified into three groups:

Non responders: anti-HBsAb level $\leq 10$ $\mathrm{IU} / \mathrm{L}$.

Weak responders: anti-HBsAb level of 10$100 \mathrm{IU} / \mathrm{L}$.

Good responders: anti - HBsAb level of $\geq$ $100 \mathrm{IU} / \mathrm{L}$.

All non responders were tested for $\mathrm{HBV}$ DNA, $\mathrm{HCV} \mathrm{Ab}$ in addition to serum transaminases.

An informed consent was obtained from all participants.

\section{Laboratory methods:}

\section{Assay of Transaminases:}

Aspartate aminotransferase (AST) and alanine aminotransferase (ALT) were assayed by International Federation of Clinical Chemistry (IFCC) method without pyridoxal phosphate, kinetic, U.V at 340 nm on Beckman Synchron CX5 Delta Clinical System (BCKCX5) (Beckman Instruments, Inc., Brea, Ca 92822-8000 USA.). Reagents were obtained from ELITech Group Co. (SEPPIM S.A.S. Zone industrially 61500 SEES France). 


\section{HBs Ag and anti HBs Abs detection:}

They were tested using HBsAg and antiHBs EIA DiaSorin S.p.A kits respectively (13040 SALUGGIA (VC), Italy).

\section{Principle:}

A typical Direct sandwich ELISA assay in which the antibody, specific for the analyte, is immobilised onto the solid phase; 96well polystyrene microtitre plate wells.

\section{Technique:}

Samples were added to the wells and any corresponding antigen is captured to form an antibody-antigen complex. A wash step is performed to remove any unbound molecules. An antibody labelled with an enzyme is added which binds to form an antibody-antigen-antibody/enzyme

conjugate complex and is followed by a wash step. A substrate solution was added, the colour produced change which is proportional to the amount of bound enzyme. Thus samples which do not contain the particular analyte will not form a complex and therefore no colour reaction will take place. Wells that contain samples that do contain the analyte will show a colour change corresponding to the number of individual complexes formed. The colour produced was measured on a spectrophotometer at wavelength $450 \mathrm{~nm}$ (reference filter 630nm).

\section{Detection of HBV DNA by Real Time Polymerase Chain Reaction (PCR):}

Viral DNA was extracted from serum using the QIAamp Min Elute Virus Spin kit (QIAGEN USA) then the extract was added to artus HBV TM PCR Master Mix ( 17 $\mu \mathrm{l}$ were taken from the artus HBV TM PCR Master Mix (ready to use) and added to $8 \mu \mathrm{l}$ of the extract to obtain the total volume $25 \mu \mathrm{l}$ ). The reaction tube was put in the Stratagene MX3000P and the thermal cycle of the device was set at: $95^{\circ} \mathrm{C}$ for 10 minutes (one cycle), $95^{\circ} \mathrm{C}$ for 15 seconds and $60{ }^{\circ} \mathrm{C}$ for 1 minute (40 cycles). The detection is based on the fluorogenic 5'nuclease assay. During the PCR reaction, the DNA polymerase cleaves the probe at the 5' end and separates the reporter dye from the quencher dye only when the probe hybridizes to the target DNA. This cleavage results in the fluorescent signal generated by the cleaved reporter dye, which is monitored real-time by the PCR detection system. The PCR cycle at which an increase in the fluorescence signal is detected initially is called threshold cycle $(\mathrm{Ct})$ and it is proportional to the amount of the specific PCR product.

\section{Statistical Methods:}

Data were analyzed using SPSS program version 15. Quantitative data were presented in mean and standard deviation and in case of presence of extreme values the median and range were used. Qualitative data were compared using frequency and percentage.

\section{Results:}

\section{Demography and BMI:}

The study included $100 \mathrm{HCWs}$ (doctors and nurses) working in Gastroenterology Department of Ain Shams University. They were 47 males and 53 females with average age $25 \pm 6.5$ years and BMI $26.5 \pm 2.3 \mathrm{~kg} / \mathrm{m}^{2}$ (table 1) 


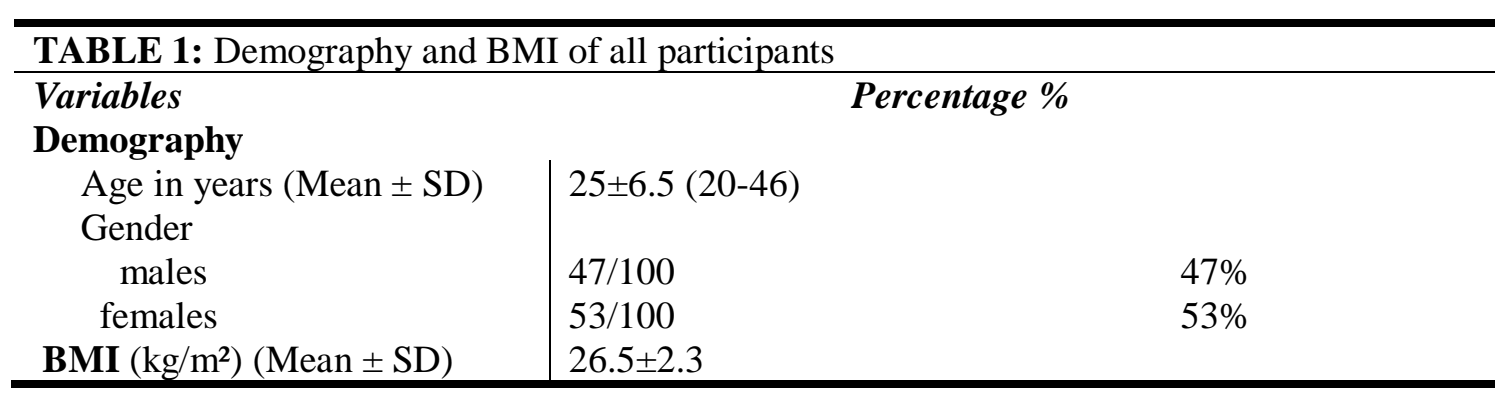

2. Immune response to $\mathrm{HBV}$ the last 5 years by hepatitis B recombinant vaccine and its relation to age vaccine; $92 \%$ showed good response to the and BMI: vaccine, $4 \%$ had adequate ( $\geq 10 \mathrm{IU} / \mathrm{L}$ ) but weak response and $4 \%$ were non responders

Anti HBs Abs were measured for all subjects who had been vaccinated within (table 2, figure 1).

\begin{tabular}{lcc}
\hline TABLE 2: Immune response to HBV vaccine & \\
\hline Response & Number of patients & HBsAb level (IU/L) (Mean \pm SD) \\
\hline Good responders & 92 & $855.6 \pm 231.6$ \\
Weak responders & 4 & $40.4 \pm 11.8$ \\
Non responders & 4 & $2.4 \pm 0.43$ \\
Total & $\mathbf{1 0 0}$ & $\mathbf{7 8 8 . 5} \pm 318$ \\
\hline
\end{tabular}

The mean age of subjects who showed good response was significantly lower than those who were weak and non responders. The mean BMI was not significantly different between all groups (table 3 ). 


\begin{tabular}{l|l|c|c}
\hline \multicolumn{3}{|c}{ TABLE 3: Relation between the mean age and BMI to the response to HBV vaccine } \\
\hline Variables & Mean \pm SD & $\mathbf{X}^{\mathbf{2}}$ & P value \\
\hline Age (years) & & & \\
Good responders & $24.5 \pm 5.9$ & 6.3 & $\leq 0.05$ \\
Weak responders & $32.3 \pm 13.4$ & & \\
Non responders & $33 \pm 7$ & & \\
BMI $\left(\mathbf{k g} / \mathbf{m}^{2}\right)$ & & & \\
Good responders & $26.4 \pm 2.2$ & 1.1 & $>0.05$ \\
Weak responders & $27.6 \pm 2.08$ & & \\
Non responders & $27.8 \pm 4$ & & \\
\hline
\end{tabular}

\section{Pattern of hepatitis serology :}

TABLE 4: Frequency of $\mathrm{HBs} \mathrm{Ag}$ and $\mathrm{HBc} \mathrm{Ab}$ in the studied subjects

\begin{tabular}{c|c|c|c|c|c}
\hline \multirow{2}{*}{ Groups } & \multirow{2}{*}{ Number } & \multicolumn{2}{|c|}{ HBs Ag } & \multicolumn{2}{c}{ HBc Ab } \\
\cline { 3 - 6 } & & positive & negative & positive & negative \\
\hline Good responders & 92 & 0 & 92 & 0 & 92 \\
\hline Weak responders & 4 & 0 & 4 & 0 & 4 \\
\hline Non responders & 4 & 1 & 3 & 2 & 2 \\
\hline \multicolumn{1}{c}{ Total } & $\mathbf{1 0 0}$ & $\mathbf{1}$ & $\mathbf{9 9}$ & $\mathbf{2}$ & $\mathbf{9 8}$ \\
\hline
\end{tabular}

All HCWs who showed seroconversion (good and weak responders) to $\mathrm{HBV}$ vaccine were negative for $\mathrm{HBs} \mathrm{Ag}$ and $\mathrm{HBc}$ $\mathrm{Ab}$. In non responders; two subjects were positive to $\mathrm{HBc} \mathrm{Ab}$ and one of them had HBs Ag detected in his serum (table 4).
Both were positive to HBV DNA and had evidence of chronic hepatitis (elevated serum transaminases) (table 5). The other 2 subjects who were non responders had no evidence of hepatitis B or C infection (table $5)$.

\begin{tabular}{l|c|c|c|c|c|c|c}
\hline \multicolumn{7}{c}{ TABLE 5: Serum transaminases and hepatitis serology for non responders. } \\
\hline $\begin{array}{l}\text { Non } \\
\text { responders }\end{array}$ & $\begin{array}{c}\text { HBsAb } \\
\text { IU/L }\end{array}$ & HBs Ag & HBc Ab & $\begin{array}{c}\text { HBV DNA } \\
\text { IU/ml }\end{array}$ & $\begin{array}{c}\text { HCV } \\
\text { Ab }\end{array}$ & $\begin{array}{c}\text { AST 0-37 } \\
\text { IU/ml }\end{array}$ & $\begin{array}{c}\text { ALT 0-42 } \\
\text { IU/ml }\end{array}$ \\
\hline Case 1 & 2 & $-v e$ & $-v e$ & $-v e$ & $-v e$ & 17 & 19 \\
Case 2 & 0 & $-v e$ & $-v e$ & $-v e$ & $-v e$ & 10 & 14 \\
Case 3 & 0 & + -ve & + ve & 2400 & $-v e$ & 62 & 45 \\
Case 4 & 0 & $-v e$ & $+v e$ & 17400 & $-v e$ & 30 & 22 \\
\hline
\end{tabular}




\section{Discussion:}

Among $100 \mathrm{HCW}$ included in this study, 96\% showed seroconversion in response to the received hepatitis B vaccine. The good responders were 92 (92\%) subjects (Their mean anti HBs Abs were 855.6 \pm 231.6 IU/L) and the weak responders were 4 (4\%) subjects (Their mean anti HBs Abs were $40.4 \pm 11.8 \mathrm{IU} / \mathrm{L})$. The non responders to HBV vaccine were only 4 subjects. These results confirm that HBV vaccine is highly effective and its introduction to our infection control program was cost effective.

Many reports from different countries described the efficacy of HBV vaccine which generally ranges between $85 \%$ to over 90\% (Keating and Noble, 2003); in Switzerland, seroconversion rate in HCWs was $95 \%$ following 3 doses of recombinant HBV vaccine (Desgrandchamps and Siegrist, 1998), while it was $86 \%$ and $86.5 \%$ in Pakistan (Zeeshan et al., 2007) and Israel (Platkov et al., 2003) respectively. Other epidemiological studies conducted in Iran (Gholamzadeh and Serati, 2006) and Saudi Arabia (Zamani et al., 2011) showed response rate to $\mathrm{HBV}$ vaccine equal to $87.3 \%$ and $82.8 \%$ respectively, in both studies not all included subjects had completed 3 doses of the vaccine. Thus, vaccination with the full dose schedule is an important determinant of the response.

We analyzed the age and BMI in the studied population in relation to the pattern of response to HBV vaccine; the mean age of good responders was significantly lower than both weak and non responders (24.5 \pm 5.9 years, $32.3 \pm 13.2$ years and $33 \pm 7$ years respectively). This agreed with many reports (Louther et al., 1998, Yen et al., 2005 and Zeeshan et al., 2007). However, Zamani et al. 2011 didn't find age a significant determinant of response to $\mathrm{HBV}$ vaccine. BMI in our study was not significantly different between different groups; it was $26.4 \pm 2.2 \mathrm{~kg} / \mathrm{m}^{2}, 27.6 \pm 2.08$ $\mathrm{kg} / \mathrm{m}^{2}$ and $27.8 \pm 4 \mathrm{~kg} / \mathrm{m}^{2}$ for good, weak and non responders respectively. All responders were negative for both $\mathrm{HBs} \mathrm{Ag}$ and $\mathrm{HBc}$ $\mathrm{Ab}$; this confirms that their serum anti HBs were developed in response to the received HBV vaccine. In non responders, two subjects were positive to $\mathrm{HBc} A b$; one of them was HBs Ag positive and both had HBV DNA in their serum. These two cases had chronic hepatitis B infection which explains the non response to the received vaccine. The other two subjects were free of infection of both hepatitis B and hepatitis $C$, yet they didn't develop protective antibodies after vaccination.

In conclusion, recombinant hepatitis $\mathrm{B}$ vaccine is cost effective and should be administered early (at young age) in full dose to all non vaccinated HCWs. Post vaccination antibodies testing in $\mathrm{HCWs}$ is not mandatory, however screening for $\mathrm{HBsAg}$ and $\mathrm{HBcAb}$ before vaccination is recommended to exclude undiagnosed infection in this high risk group.

\section{References:}

4. Chang MH (2011): Hepatitis B virus and cancer prevention. Recent Results Cancer Res; 188:75-84.

5. Desgrandchamps D, Siegrist CA. (1998): Vaccination against hepatitis B. Soz Praventivmed; 43 (1): S37-40, S111-4.

6. Gabbuti A, Romanò L, Blanc $\mathbf{P}$, Meacci F, et al. (2007): Long-term immunogenicity of hepatitis B vaccination in a cohort of Italian healthy adolescents. Vaccine; 25(16): 3129-32.

7. Gholamzadeh S, Serati AR. (2006): The long-term immunity among health care workers vaccinated against hepatitis $\mathrm{B}$ virus in a large 
referral hospital in southern Iran. Arch Iran Med; 9(3): 204-7.

8. Hennig BJ, Fielding $\mathbf{K}$, Broxholme $\mathbf{J}$, Diatta M, et al. (2008): Host genetic factors and vaccine-induced immunity to hepatitis B virus infection. PLoS ONE: Research Article, HBV Vaccine Genetics. 2008; 3 (3): e1898. www.plosone.org

9. Keating GM, Noble S. (2003): Recombinant hepatitis B vaccine (Engerix-B): a review of its immunogenicity and protective efficacy against hepatitis B. Drugs; 63(10): 1021-51.

10. Kwon SY, Lee CH. (2011): Epidemiology and prevention of hepatitis B virus infection. Korean $\mathrm{J}$ Hepatol; 17(2): 87-95.

11. Louther J, Feldman J, Rivera $\mathbf{P}$, Villa N, et al. (1998): Hepatitis B vaccination program at a New York City hospital: seroprevalence, seroconversion, and declination. Am J Infect Control; 26(4):423-7.

12. Ni YH, Chang MH, Huang LM, Chen HL, et al. (2001): Hepatitis B virus infection in children adolescents in a hyperendemic area: 15 years after mass hepatitis B vaccination .Ann intern.Med; 135(9):796-800.

13. Pallás Alvarez JR, Gómez Holgado MS, Llorca Díaz J, Delgado Rodríguez M. (2000): Hepatitis B vaccination. Indications of the postvaccine serologic test and booster doses. Rev Esp Salud Publica; 74(5-6): 475-82.

14. Platkov E, Shlyakhov E, Glick Y, Khalemsky S, Fischbein A. (2003): Immunologic evaluation of hepatitis B vaccine application in hospital staff. Int J Occup Med Environ Health; 16(3): 249-53.
15. Scolnick EM, Mclean AA, West DJ, McAleer WJ, Miller WJ. (1985): Clinical evaluation in healthy adults of a hepatitis $B$ vaccine made by recombinant DNA.JAMA; 251 (21): 2812-5.

16. Shatat HZ, Kotkat AM, Farghaly AG. (2000): Immune response to hepatitis $\mathrm{B}$ vaccine in haemodialysis patients. J Egypt Public Health Assoc; 75(3-4):257-75.

17. Thakur V, Pati NT, Gupta RC, Sarin SK. (2010): Efficacy of Shanvac-B recombinant DNA hepatitis $\mathrm{B}$ vaccine in health care workers of Northern India. Hepatobiliary Pancreat Dis Int; 9(4): 393-7.

18. Van Damme P, Van Herck K. (2007): A review of the long-term protection after hepatitis A and B vaccination. Travel Med Infect Dis: 5(2): 79-84.

19. Yen YH, Chen CH, Wang JH, Lee CM, Changchien CS, Lu SN. (2005): Study of hepatitis B (HB) vaccine nonresponsiveness among health care workers from an endemic area (Taiwan). Liver Int; 25(6):1162-8.

20. Zamani F, Fallahian F, Hashemi F, Shamsaei Z, Alavian SM. (2011): Immune response to hepatitis B vaccine in health-care workers. Saudi J Kidney Dis Transpl; 22(1):179-84.

21. Zannolli R, Morgese G. (1997): Hepatitis B vaccine: current issues. Ann Pharmacother; 31(9):1059-67.

22. Zeeshan M, Jabeen K, Ali AN, Ali AW, et al. (2007): Evaluation of immune response to Hepatitis B vaccine in health care workers at a tertiary care hospital in Pakistan: an observational prospective study. BMC infectious Disease; 7:120 doi: 10.1186/1471-2334-7-120. 
الإستجابة المناعية للتطعيم ضد الفيروس الكبدي (ب) في العاملين بمجال الصحة

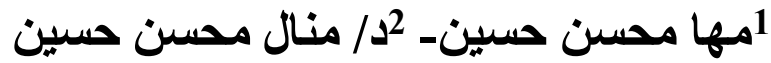

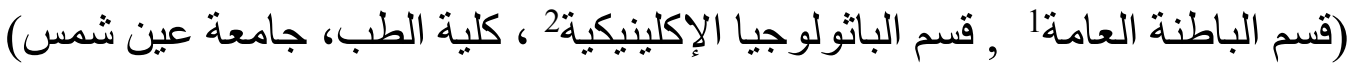

المقدمة: يشكل العاملون بمجال الصحة مجموعة من الأفر اد ذو خطورة للعدوى بالفيروس الكبدي

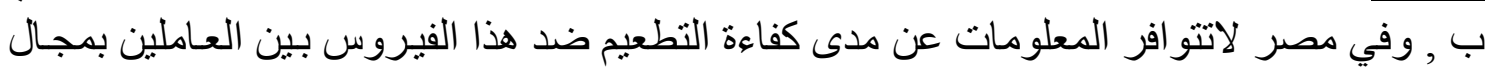
الصحة

اللهف من الدراسة: تقييم كفاءة التطعيم ضد الفيروس الكبدي ب بين العاملين بمجال الصحة في مستشفى عين شمس الجامعي.

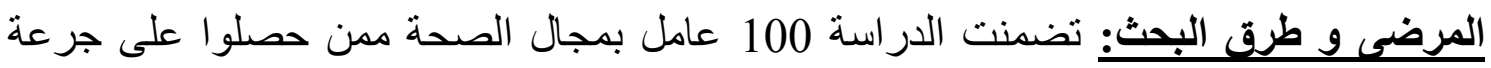

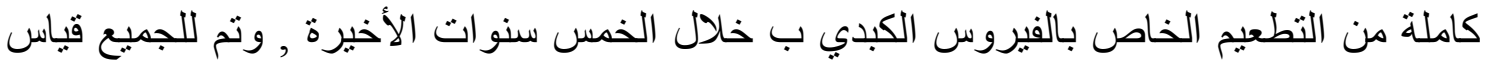
دلالات الفيروس الكبدي ب الأتية: الأجسام المضادة للأنتيجين S و الأنتيجين S و الأجسام المضادة لألياد

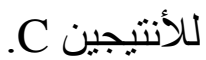

النتائج: لقدوجدت الدراسة أن 969 \% م من حصلوا على جرعة كاملة من التطعيم الخاص

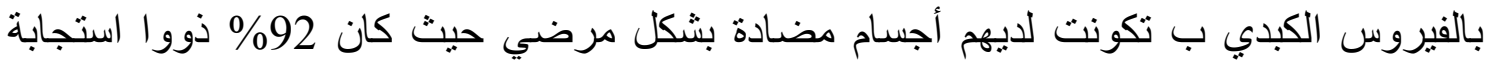
عالية و 4\% ذووا استجابة ضعيفة , ووجد أن 4\% لم لم تتكون لايهم أجسام مضادة ( غير مستجيبين)

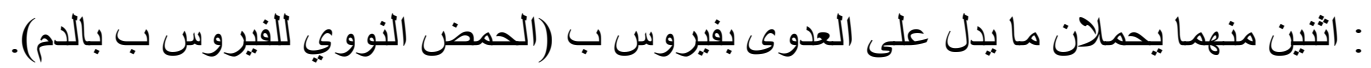

الاستنتاج:التطعيم ضد الفيروس الكبدي (ب) للعاملين بمجال الصحة ذو كفاءة عالية وبالتالي فهو مجدي بالنسبة للتكلفة ومن المفضل الإختبار عن وجود أو عدم وجود عدوى لإيل اللبل التطعيم. 